\title{
The Movement To Cyberbanking
}

Ray E. Whitmire, (E-mail: rwhitmire@cob.tamucc.edu), Texas A\&M University, Corpus Christi Steven D. Hall, (E-mail: shall@cob.tamucc.edu), Texas A\&M University, Corpus Christi

Elwin R. Myers, Texas A\&M University, Corpus Christi

\begin{abstract}
Five hundred financial institutions in the United States are randomly sampled each year in order to examine Internet participation present and planned by the financial institutions. Each year CEOs of selected institutions are asked about the institution's present involvement with on-line banking and their internet plans for the next two years. The usable response rates achieved in these studies have exceeded 40 percent. This paper examines the responses for the year 2001.
\end{abstract}

\section{Review of the Literature}

Cyber Dialogue, an online market research company, reports that the number of people who conduct their financial transactions online is expected to more than triple by 2002, from 6.9 million in 1998 to 42.2 million. The Internet is leveling the playing field and allowing alternative financial institutions to increasingly become "portal" sites that allow them to bundle an unprecedented array of products. David Llewellyn, Professor of Money and Banking at Loughborough University made the following prediction:

Banks as we know them will soon cease to exist. Banks should recognize that the move by supermarkets into banking is a Trojan horse. National Westminster has already recognized the dangers, and tore up the five year financial services agreement it arranged last summer with Tesco.

The key to an effective and decent web site is to get people to come back, says Mark O'Brien of EDS. O'Brien suggests that financial institutions start with balances and transfers, then advance to bill payment (Totty, 1999).

The Internet is also increasingly used to enhance the competitive rates and services of many different financial institutions through a new site that tracks more than 11,000 banks, savings and loans, and credit unions in 175 markets nationwide. This site provides help in analyzing interest rate performance, financial stability and local fluctuations. Ways in which reporters can use the site for business research and writing are also discussed (Bowen, 1998).

The slow increase in Internet usage by the consumer is the direct result of no material cash savings for the customer. Internet banking offers significant savings to the bank, but none of this savings is being passed on to the user in the form of higher interest rates on savings or lower costs on loans. There is no economic advantage for the consumer to use Internet banking (Nadler, 2000).

Banks, particularly community banks, are recognizing almost limitless marketing opportunities available in cyberspace. In 1997, Bagwell projected that the number of community banks on the Internet would more than double, from $21 \%$ to $48 \%$. Twenty-seven percent of these banks expected customers to be able to conduct transactions through their web sites by the end of 1997. Texas Community Bank in Dallas was reported in development of a web site to market its small business loans and home mortgages. The First National Bank of Pryor, Oklahoma was reported to be using its web site to offer small aircraft loans and provide information on the general aviation market. Even though banks were reported moving toward Internet use, credit unions appeared to be moving faster and offering a wider array of financial services (Bagwell, 1997). Banks are being out-hustled by securities industry competitors. e.Schwab and E-Trade Group have gone mainstream. Dean Witter Discover \& Co acquired Internet broker Lombard.com in December. Lombard of

Readers with comments or questions are encouraged to contact the authors via email. 
$\underline{\mathbf{2}}$

fered the QuickQuote insurance and annuity pricing service free to subscribers, and Paine Webber Inc went on line with Paine Webber Edge. Virtually every major firm now has something capable of giving banks a literal run for their money on the World Wide Web. "Unlike banks, they can concentrate on the idea of value-added, rather than on how do they move people from old to new delivery channels," said Bill Burnham, a Booz-Allen \& Hamilton consultant (American Banker).

The United States is not the only country where financial institutions are facing an ever-increasing competitive challenge. Australian banks are facing their biggest competitive challenge in decades. Non-bank mortgage lenders and declining interest rates are the reported factors. One response to meet this challenge is utilization of the Internet (Chow, 1997).

In line with competition, an e-mail survey of the 24 Internet-only banks conducted by American Banker resulted in nine responses. The American Banker was attempting to discover how many Internet banks are too many. The results from the survey indicated a confidence that there is room for everyone and that the niche strategies most Internet only banks are pursuing will ultimately pay off. One such strategy is used by National InterBank, which targets "Web savvy individuals, 18-44 years old," and has 6,500 customers, of which 500 of whom were Internet-only. "National InterBank is unique in that there are virtually no fees--free bill-pay, free checking, free account research, free worldwide ATM withdrawal, free money transfers, free stop-payments, free cashiers' checks, free statement and check reprints, no-annual-fee credit card" (Ptacek, 2000).

In 1995, Salem Five Cents Savings Bank became the first bank in New England to introduce web-based banking services. It is now planning to offer free Internet access to anyone. Salem is trying to carve out a niche in the Internet banking arena. The largest Internet operation belongs to Wells Fargo. It grows by 100,000 customers a month and boasts 1.7 million active online users, $25 \%$ of the bank's retail checking households (Power, 2000).

The definition of traditional financial services may in fact be changing. Entities unrestrained by regulation, such as investment companies, credit card companies, and technology suppliers will control financial information with the ability to transmit and use data more quickly and efficiently than banks and credit unions. The payment system is the last vested monopoly of these latter institutions and could be replaced by the replacement of physical money with electronic equivalents that could be transmitted over the Internet by an assortment of institutions (Vartanian, 1997).

Microsoft has joined other non-banks (specifically Intuit makers of Quicken) in developing web sites that give people the ability to consolidate all of their financial information in one place. Microsoft's MoneyCentral had 4.3 million visitors in March of 2000, whereas Intuit's web site had 3.6 million. The largest Internet bank had only 2.0 million. MoneyCentral became the first web site to introduce OneSource Network account aggregation software from Corillian Corporation. MoneyCentral uses OneSource to collect information on bank and credit card accounts; so far six brokerage houses, Fidelity Investments, Charles Schwab \& Co., DLJ Direct Inc., Datek Online, TD Waterhouse Group, and E-Trade Group Inc. share information with OneSource. Using Open Financial Exchange standard (OFE), which enables the sharing of information between willing institutions, these non-banks can gather information for the customer from various sources. If an institution does not have OFX or does not want to participate, a controversial practice that uses screen-scraping techniques is used to get customers' data (Toonkel, 2000).

Financial institutions' concerns regarding financial security are well founded. Dan Farmer, co-author of the Security Administrator Tool for Analyzing Networks (SATAN), recently tested more than 1,700 Internet sites and found that more than $60 \%$ of them--including banks and credit unions--could be broken into or destroyed relatively easily. Some firms failed to take even the most basic security measures to protect their server and files (Farmer, 1997).

Matrix Information and Directory Services estimates that 27.5 million people use e-mail and 20 million use the Internet interactively. Banks and credit unions need to plan their strategies by knowing who their market is, where they are located, what services they desire, and what incentives can be offered (Varela, 1996).

A survey on Internet banking and consumer behavior conducted by Gerald D. Verdi \& Co. found that Internet 
$\underline{\mathbf{2}}$

users continue to value brick and mortar banks. This survey found that 70 percent of Internet banking customers had visited a branch in the past 30 days and that the average Internet banking customer averaged more than three teller visits per month. Internet bank customers accessed their accounts online 13 times per month. The findings of the study showed that of the "participants who spent two years online, 29 percent signed up for Internet banking, compared with only 13 percent of those with less than two years of Internet usage."

Robinson found that customers of financial institutions that sign up for Internet banking haven't abandoned other methods of banking. Banks have found that adding channels didn't decrease business in other areas, but rather spread it around. The Internet is only a single channel of a multiple channel delivery system. Robinson found that fewer than $5 \%$ of bank customers sign up for Internet banking, while more than 50\% of the banking customers' households have PCs. He also identified that half the people who attempt online banking don't log back on (Robinson, 2000).

Three factors may well determine on-line banking services. These are convenience, choice and price. The high number of credit unions providing for payment of bills, along with the movement's longstanding application of payroll deduction, bodes well for their movement into the electronic revolution (Muckian, 1995).

The growth of a banking service company that provides computer services primarily for financial institutions (Fiserv, Inc.) stated that the rate of growth that this company has seen in the last year was much better than expected. This company's sales of front-end Internet banking software and processing of online banking transactions, generated revenue at an annual rate of $\$ 50$ million this year, compared with approximately $\$ 15$ million last year (Marianovic, 2000).

A banking web site is so cheap compared to a branch site that banks should not worry about the budget to startup this type of operation. In a study done by Chicago-based Grant Thornton LLP, more than a third of small-bank executives espoused that they do not have web banking now but would by year-end. In the Grant Thornton study they found that only $29 \%$ of the banks surveyed said their customers wanted Internet banking service. Their study found that only $17 \%$ of community banks offer Internet service and of those that do banking services are quite limited. Only $21 \%$ offer bill payment, $11 \%$ loan applications, and 30\% cash management services. Those figures are expected to rise to $87 \%$, $75 \%$, and $72 \%$, respectively, by 2003 . This study found that $87 \%$ of the banks that offer Internet banking services or plan to this year would do so through a third-party provider. Bankers in that study compared Internet banking to ATMs in that services may not be sought at the beginning, but given a few years the demand will increase (Agosta, 2000).

In a conversation with top executives from four tech-savvy community banks with assets of under $\$ 400$ million, these bankers identified that the capabilities available through the Internet are becoming as necessary in doing business as fax machines, pagers, and cell phones. They felt that the community banking industry has to be technologically aggressive to remain competitive. They identified that for a small investment a bank could offer an Internet presence and could offer billpaying capabilities. The Internet offers a small bank the opportunity to expand their trading area. Small banks tend to have to evaluate their e-banking vendor on a number of criteria. Several criteria identified were financial stability, commitment to ongoing enhancements, security, Internet connections, technical support, marketing support, training on the product and ease in interfacing data with the product (O'Connell, 2000).

\section{Methodology}

The purpose of this study was to determine the extent to which financial institutions in the United States are currently involved in Internet banking activities. It also sought to discover any plans to increase their presence on the Internet in the future. A questionnaire was mailed to approximately 500 randomly selected CEOs of financial institutions in the United States in mid-2001; this group was targeted because it was felt that CEOs were most likely to know the short-term goals and objectives of their institutions. This 2001 study is the most recent reporting of an annual longitudinal study that began in 1997.

A single page, two-sided questionnaire was developed and tested by a control group for ease of use and understanding. Modifications were made to the questionnaire in response to recommendations from the control group. Address labels were purchased from an outside research company that randomly generated the names of CEOs of financial institu- 
$\underline{\mathbf{2}}$

tions in the United States and its possessions. The survey instrument was numbered and sent to the sample in three different mailings, or until a response was received. The questionnaire was first mailed out in August. Subsequent mailings were repeated in September and October.

The mailings resulted in 148 usable responses, a return rate of 24 percent. Although an equal number of survey instruments were sent to bank and credit unions, they were returned in much greater number by the credit unions. Credit union respondents returned 102 completed survey forms (68.9\%); banks respondents submitted 46 forms (31.1\%).

\section{Results and Discussion}

The survey contained several questions that sought to identify the financial institutions' current and future levels of involvement with Internet banking activities. The survey contained additional questions that probed related areas, such as potential obstacles to Internet involvement, personnel used for handling Internet banking resources, and fees charged for accessing financial information on-line.

\subsection{Levels of Involvement with Internet Banking}

Responses were examined in an effort to determine change in the institutions' Internet perspective. Also explored was the type of activity that presence would provide (i.e., the level of sophistication of Internet presence, both current and planned). If the respondents expressed no intention of going onto the Internet, the questionnaire attempted to ascertain why. If the respondent expressed intentions of going onto the Internet but did not intend to offer full-service banking capabilities, again the questionnaire attempted to ascertain why.

Financial institutions were divided into three classifications of involvement, as shown in Table 1. The first classification includes only those institutions that currently have an Internet presence. The second classification represents those institutions that are not presently on the Internet but are planning to have an Internet presence within two years. The third classification includes only those financial institutions that have no plans for an Internet presence within two years.

\subsection{Current Internet Participation}

A majority of the financial institutions (72\%) already report an Internet presence of some sort. When combined with the percentage that is not currently involved but predict a presence within the next two years, the percentage of financial institutions on the Internet within two years is expected to be nearly 85 percent. Only 16 percent do not anticipate being involved with Internet banking within the next two years. Their reasons for not participating in Internet banking activities are explored in a later table

Table 1 Internet Participation and Planned Participation of Respondents

\begin{tabular}{|l|c|}
\hline Internet Participation Status & Percentage of Respondents \\
\hline & $(\mathrm{n}=148)$ \\
\hline Presently on the Internet & $72.3 \%$ \\
\hline $\begin{array}{l}\text { Plan to be on Internet within two } \\
\text { years }\end{array}$ & 11.5 \\
\hline No plans for Internet presence & 16.2 \\
\hline Total & 100.0 \\
\hline
\end{tabular}

The larger the institution, the more likely it was to have an Internet presence. About 52 percent of institutions with total assets under $\$ 50$ million reported an Internet presence, and another 19.8 percent planned to go on within the next two years. Institutions with assets exceeding \$50 million had 93 percent Internet involvement. Not surprisingly, the smaller institutions were considerably more likely to have no plans for Internet involvement (27.6 percent) than were the larger ones (4.2).

\subsection{Present Levels of Internet Involvement}

Respondents were asked to provide an assessment of their institutions' current Internet banking activity. Five 
$\underline{2}$ different involvement levels were provided to help assist respondents in classifying their responses (see Table 2). The lowest level, Level 0, signifies no Internet involvement; the remaining four levels represent an ascending order of Internet presence. As revealed earlier, nearly 30 percent of the total respondents reported no Internet involvement. Some of those institutions anticipate an Internet presence within the next two years; others do not. Those statistics will be reported later along with some of the obstacles that have discouraged Internet participation

Table 2

Present Level of Internet Involvement by Total Respondents

\begin{tabular}{|l|c|c|}
\hline Levels of Sophistication & Respondents presently on Internet & All Respondents \\
\hline & $(\mathrm{n}=107)$ & $(\mathrm{n}=148)$ \\
\hline Level 0 (not on Internet) & $0.0 \%$ & $27.7 \%$ \\
\hline Level 1 (provides information) & 17.7 & 12.8 \\
\hline Level 2 (receives information) & 7.5 & 5.4 \\
\hline Level 3 (shares information) & 5.6 & 4.1 \\
\hline Level 4 (processes information) & 69.2 & 50.0 \\
\hline
\end{tabular}

Level 1 represents an institution's ability to provide basic information about itself without allowing for any customer interaction. An example of an institution categorized as a Level 1 institution would be one that solely uses an electronic bulletin board. Customers may access the information the institutions have posted; however, customers are not able to respond to the information on-line. The survey revealed that 17.7 of institutions currently using the Internet reported that their institutions' Internet involvement was at the Level 1 stage. When considering all survey respondents, the percentage drops to 12.8 percent.

Some institutions have the capacity to allow customers to submit certain kinds of information. Those institutions are categorized as Level 2 institutions. Examples of submissions that customers might make to Level 2 institutions over the Internet include transmission of loan or credit card applications. Approximately 7 percent of institutions currently using the Internet reported that their institutions' Internet involvement was at the Level 2 stage. When considering all survey respondents, the percentage drops to 5.4 percent.

The next higher level is Level 3. Level 3 institutions are able to share information between the institution and the customer. An example of a Level 3 transaction might be where customers are able to check their account or loan balances on-line. The survey revealed that 5.6 of institutions currently using the Internet reported that their institutions' Internet involvement was at the Level 3 stage. When considering all survey respondents, the percentage drops to 4.1 percent.

Finally, the highest level is Level 4. Financial institutions using Level 4 have the capacity to allow their customers to actually process its information online. Level 4 is by far the most prevalent among survey respondents. Nearly 70 percent of respondents claim to have some sort of information-processing capability. When considering all survey respondents, the percentage drops to 50 percent.

Institutions with Level 4 capabilities were asked about their ability to provide software interface and bill-paying capacity for their customers. A majority of respondents $(80.2 \%)$ indicated that their institutions currently provide software interface, 17.3 percent said their institutions did not, and 2.5 percent were uncertain. Again, a majority of respondents $(64.9 \%)$ indicated an online bill-paying capacity for customers while 35.1 percent did not.

\subsection{Current Internet Involvement Level by Financial Institution Type}

Banks and credit unions seem to be operating at different levels of Internet involvement. Credit unions that report Internet presence apparently do so at lower levels of sophistication, as shown in Table 3. More than half the credit unions with Internet presence report a current presence at Level 1 (32.1\%) or Level 2 (28.6\%). Only a quarter of banks, 
$\underline{2}$ however, report a presence at either Levels 1 or 2.

Table 3

Present Level of Internet Involvement by Financial Institution Type

\begin{tabular}{|l|c|c|c|}
\hline Levels of Sophistication & Banks on Internet & CUs on Internet & All Respondents \\
\hline & $(\mathrm{n}=34)$ & $(\mathrm{n}=73)$ & $(\mathrm{n}=148)$ \\
\hline Level 1 (provides information) & 20.6 & 32.1 & 12.8 \\
\hline Level 2 (receives information) & 5.9 & 28.6 & 5.4 \\
\hline Level 3 (shares information) & 5.9 & 3.6 & 4.1 \\
\hline Level 4 (processes information) & 67.6 & 35.7 & 50.0 \\
\hline
\end{tabular}

Banks currently on the Internet report a significantly higher involvement at Level 4 (67.6 percent versus 35.7 percent). When combining both groups, over half the total respondents claiming an Internet presence report an Internet involvement at the higher levels.

\subsection{Future Level of Internet Involvement}

Respondents not currently using Internet banking were asked about possible future involvement. Specifically, they were asked to indicate whether they expected to have an Internet presence within the next two years. If they indicated an expected involvement, they were then asked about the level of that involvement, as reported in Table 4. Seventeen respondents indicated that their institutions had plans for an Internet presence within two years. Half of those respondents selected one of the lower levels (Levels 1 or 2), and the other half indicated an immediate presence at the highest level (Level 4).

Table 4

Future Level of Internet Involvement by Respondents (\%), 2001

\begin{tabular}{|l|c|c|c|c|}
\hline Levels of Sophistication & $\begin{array}{c}\text { Future Internet } \\
\text { Presence of } \\
\text { Institutions With a } \\
\text { Current Internet } \\
\text { Presence }\end{array}$ & $\begin{array}{c}\text { Future } \\
\text { Internet Presence of } \\
\text { Institutions With } \\
\text { No Current } \\
\text { Presence }\end{array}$ & $\begin{array}{c}\text { Future Internet } \\
\text { Presence of All } \\
\text { Institutions Seeking } \\
\text { a Future } \\
\text { Presence }\end{array}$ & $\begin{array}{c}\text { Future Internet } \\
\text { Presence of All } \\
\text { Respondents }\end{array}$ \\
\hline Level 0 (not on Internet) & $(\mathrm{n}=102)$ & $(\mathrm{n}=17)$ & $0.0 \%$ & $(\mathrm{n}=119)$ \\
\hline Level 1 (provides information) & $0.0 \%$ & $0.0 \%$ & 9.2 & $19.6 \%$ \\
\hline Level 2 (receives information) & 4.9 & 23.5 & 8.4 & 7.4 \\
\hline Level 3 (shares information) & 2.9 & 29.4 & 2.5 & 6.8 \\
\hline Level 4 (processes information) & 85.3 & 0.0 & 79.8 & 2.0 \\
\hline
\end{tabular}

When the respondent group already on the Internet is added to the emerging group, nearly 85 percent of the total number of respondents indicated either a current or anticipated presence within the next two years. Interestingly, over 15 percent of all respondents report no immediate plans for Internet activity. That group no doubt had considered the advantages and disadvantages of Internet banking, but nonetheless opted to continue with its existing means of communicating with its customers. Some of the reasons provided by the financial institutions are provided in the next section.

\subsection{Obstacles Hampering Internet Banking}

A large majority of respondents indicated that their financial institutions either already had an Internet presence or anticipated having one within the next two years. Approximately 20 percent of the respondents, however, revealed that their institutions had no immediate plans of participating in Internet banking. These respondents were asked to share the reasons they had for choosing to not participate in Internet banking. The results are presented in Table 5 . 
Table 5 Obstacles Identified by Financial Institutions Not Seeking an Internet Presence $(\mathbf{n}=29)$

\begin{tabular}{|l|c|}
\hline Obstacles & \% of Respondents \\
\hline & \\
\hline Insufficient Demand & 36 \\
\hline Cost & 22 \\
\hline Loss of Personal Contact & 14 \\
\hline Financial Security & 12 \\
\hline Programming Difficulty & 4 \\
\hline Other & 12 \\
\hline
\end{tabular}

The most commonly reported response for avoiding an Internet banking presence was insufficient demand. Respondents apparently felt that their customers were well served and satisfied with current communication operations; the Internet simply would not likely make much of a difference. Another commonly provided response was the cost involved in introducing and maintaining an Internet site. Some institutions may worry that the personnel, hardware, and on-line costs would be too expensive for any resultant benefit that may occur. The third most commonly provided response was loss of personal contact. Perhaps the institution prided itself on personal customer relations and feared the Internet would appear counter to that objective. Although the Internet may appeal to some customers, it may alienate others. They may interpret the Internet presence as an attempt for the institution to provide less direct contact with them.

\subsection{Personnel Used for Handling Internet Activities}

Earlier tables clearly show the widespread usage of Internet banking by both types of financial institutions. Respondents who reported Internet use were asked how their institutions chose to implement it. Institutions may choose to have the tasks needed to implement its Internet involvement performed by personnel the institution already employs. Institutions may instead choose to have those tasks outsourced, or performed by people who work for companies that specialize in Internet design and maintenance.

Institutions that choose to have the Internet tasks performed in-house may either hire new employees or use existing personnel. Existing personnel may have already been employed in another capacity but either volunteered or were required to assume the Internet duties.

Respondents revealed that 44.4 percent of all financial institutions have the Internet tasks performed in-house and 55.2 percent have the tasks outsourced to outside firms, as shown by Table 6. Banks were much more likely to have the tasks performed in-house (59.9\%) than were credit unions (41\%). The reasons for this difference is unknown; however, perhaps banks have larger staffs with a broader range of employee skills from which to tap.

Table 6

Present Method of Accessing the Internet by Type of Institution

\begin{tabular}{|l|c|c|c|}
\hline Method of Accessing & Banks & Credit Unions & Both \\
\hline & $\begin{array}{c}(\mathrm{n}=34 \\
)\end{array}$ & $(\mathrm{n}=73)$ & $(\mathrm{n}=107)$ \\
\hline In-house Personnel & $52.9 \%$ & $41.1 \%$ & $44.8 \%$ \\
\hline n & & $\mathbf{5 0} \mathrm{n}$ \\
\hline
\end{tabular}

Respondents who indicated that their web site was designed and maintained in-house were asked how the staff was developed. Institutions that chose to have the function performed inhouse could have either hired someone new, used a current employee with sufficient pre-existing skill, or used an existing employee requiring specialized training. Table 7 shows that a majority of institutions that opted for in-house maintenance trained their own employees.

Table 7

Methods of Obtaining and Maintaining an Internet Presence

\begin{tabular}{|l|c|c|c|c|c|c||}
\hline & \multicolumn{3}{|c|}{ Institutions Already On Internet } & \multicolumn{3}{|c||}{ Institutions Planning to Go on Internet } \\
\hline & Banks & Credit Unions & Both & Banks & Credit Unions & Both \\
\hline & $\mathrm{n}=17$ & $\mathrm{n}=27$ & $\mathrm{n}=44$ & $\mathrm{n}=6$ & $\mathrm{n}=19$ & $\mathrm{n}=25$ \\
\hline Hired New Employee & $11.8 \%$ & $14.8 \%$ & $13.6 \%$ & $0.0 \%$ & $15.8 \%$ & $12.0 \%$ \\
\hline Employee Trained & 52.9 & 37.0 & 43.1 & 50 & 47.4 & 48.0 \\
\hline
\end{tabular}


2

Employee Experienced

35.3

48.2

43.1

50

36.8

40.0

Institutions with an asset size of $\$ 50$ million or less that already have an Internet presence reported that 50 percent trained a current employee, 41.7 percent located an employee with the needed skill, and 8.3 percent hired someone new. The larger institutions (more than $\$ 50$ million in assets) also used a large number of employees specifically trained to perform the task (40.6\%); however, these institutions used even more employees already possessing the skill (43.8\%). The larger institutions also were least likely to hire new employees (15.6\%).

Institutions planning to go on the Internet within two years were also asked which method they anticipated using to make their Internet presence. The three possible responses appeared in the same order as reported for those institutions already with an Internet presence. Training an existing employee was most popular again for both the larger- and smaller-sized institutions. This time, however, the larger-sized banks had a higher response (50\%) for training than did the smaller ones $(46.1 \%)$.

When respondents were given the chance to share their expectations about future methods of accessing the internet, the results were different from those mentioned by current users. "Outsourced personnel" was the most commonly mentioned response for both groups, as shown in Table 8. Several interesting observations arise from the results of Table 8. The banks considering an imminent Internet presence differed completely with those banks already providing services on the Internet. This time the emerging banks favored “outsourced personnel” by a wide margin ( $60 \%$ versus $30 \%)$; current Internet banks preferred having the service provided in-house. Perhaps the banks anticipating an entrance into Internet banking realize they're somewhat behind other institutions and have chosen to expedite the process by using the services of experts in the field.

Table 8

Anticipated Future Method of Accessing the Internet by Type of Institution

\begin{tabular}{|l|c|c|c|}
\hline Method of Accessing & Banks & Credit Unions & Both \\
\hline & $\begin{array}{c}(\mathrm{n}=20 \\
)\end{array}$ & $(\mathrm{n}=53)$ & $(\mathrm{n}=73)$ \\
\hline In-house Personnel & $30.0 \%$ & $34.0 \%$ & $32.9 \%$ \\
\hline Outsourced Personnel & 60.0 & 56.6 & 57.5 \\
\hline Undecided & 10.0 & 9.4 & 9.6 \\
\hline
\end{tabular}

Both groups of credit union respondents (current users and imminent users) indicated that using outsourced personnel is the preferred method of accessing the Internet. Surprisingly, the percentages for both groups was nearly identical (58\% versus 56\%). The reasons why credit unions feel compelled to select outside assistance is unknown; however, perhaps they feel they can best use their human resources by continuing to concentrate on financial rather than computerrelated tasks. Also worth noting is the relatively large percentage of "undecided" responses for both credit unions and banks.

\subsection{Fees Charged for Accessing Financial Information Online}

A majority of financial institutions do not charge for their Internet banking services, as shown in Table 9. When considering both types of financial institutions, only 28 percent charge; 69 percent do not charge. The credit unions were much less likely to charge. Only about 20 percent of credit unions report charging for their on-line banking services; the banks report a percentage about double that $(40 \%)$.

Table 9

Fee Assessment For Use of Internet Services by Type of Institution

\begin{tabular}{|l|c|c|c|}
\hline & Banks & Credit Unions & Both \\
\hline & $\begin{array}{c}(\mathrm{n}=27 \\
)\end{array}$ & $(\mathrm{n}=51)$ & $(\mathrm{n}=78)$ \\
\hline Fees Charged & $40.7 \%$ & $19.6 \%$ & $28.6 \%$ \\
\hline No Feac Charred & 502 & $8 \mathrm{2} /$ & $60 \mathrm{8}$
\end{tabular}




\section{Conclusions}

Banks and credit unions apparently recognize the value of an Internet banking presence. A majority of both types of financial institutions are already on the Internet; however, banks are present in greater percentages. In addition to those institutions already present, many more are making plans to provide on-line services to their customers. Although in the minority, a sizable number still choose to provide their banking services exclusively off-line. One can only wonder whether competitive pressures will some day force these reluctant institutions to rethink their decision

\section{References}

1. Agosta, V. (2000, April 28). Small Banks Won't Be Web Holdouts for Long. American Banker, New York: $12 \mathrm{a}$.

2. Bagwell, J. (1997, October). Community banks offer innovative Websites. Bank Marketing, $29(10): 13$.

3. Bowen, C. (1998, May 16). Of interest at Rate.net. Editor \& Publisher, 131(20):34.

4. Chow, L. (1997, September 25). Pressure Rising. Far Eastern Economic Review, 1690(39):125-130.

5. Editor, (1996, June). An Internet Banking Boom is Coming... Really. United States Banker, 106(6), p.20.

6. Kearns, D. (1997, January 6). Time for an NT Security Checkup. Network- World, 14(1):22.

7. Marjanovic, S. (2000, May 2). Fiserv Wary of Its E-Commerce Businesses, Though They Grow Fast. AmericanBanker, New York 165(84):11.

8. Muckian, M. (1995, July). Self-service at Home. Credit Union Magazine, 61(7): 36-42.

9. Nadler, P. S. (2000, May/June). Fact and fiction in Internet banking. The Secured Lender, New York 56(3):44-48.

10. O'Connell, B. (2000, June 6). Online: Seizing the Opportunities in Electronic Banking. American Banker, New York 165(108):15x.

11. Power, C. (2000, June 5). Salem Five Nurtures Its Online Pioneer Status. American Banker, New York 166(107): 1 .

12. Ptacek, M. J. (2000, May 18). On-Line Banking: Web Teeming with Banks Seeking Niches. American Banker, New York 165(96): 12.

13. Robinson, T. (2000, April 17). Internet banking: Still not a perfect marriage. Informationweek, Manhasset (782):104106.

14. Toonkel, J. (2000, May 10). New Microsoft Challenge to Banks: Account Aggregation on MSN Site. American Banker New York 165(90):1.

15. Totty, P. (1999, July). Internet level the playing field for all Cus. Credit Union Magazine, 65(7): 77-99.

16. Varela, P. (1996, September/October). Marketing and the Internet. Credit Union Executive, 36(5): 32-36.

17. Vartanian, T. (1997, February). A Cashless World. Credit Union Executive, 36(5):32-36.

18. Verdi, G. D. (2000, June 16). Traditional Banks Should Integrate Web Banking with the Branch Network. American Banker, New York 165(116): 16. 
Notes 